\title{
The relationship between readiness to change and work engagement: A case study in an accounting firm undergoing change
}

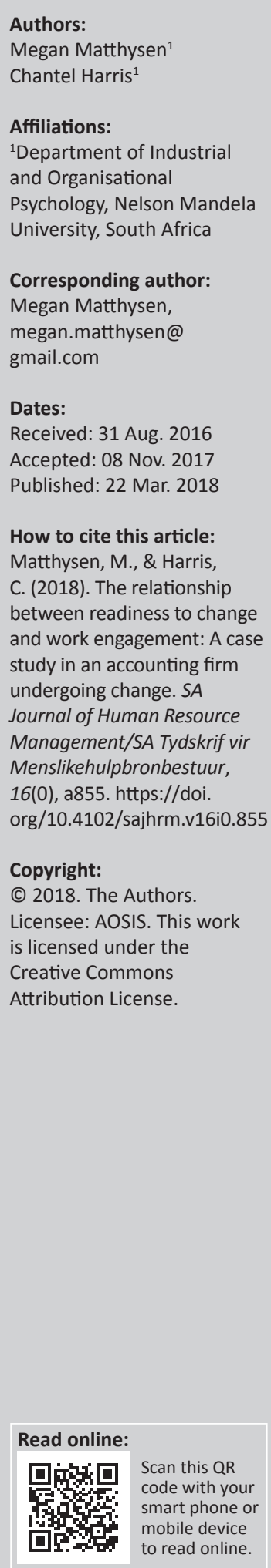

Orientation: Readiness to change is a critical element for the successful implementation of organisational change. Work engagement ensures that employees are committed to the organisations' goals and is an important driver for organisational success. It is important that organisations sustain work engagement during organisational changes.

Research purpose: To investigate the relationship between readiness to change and work engagement within an accounting firm.

Motivation for the study: A change process can only be implemented successfully if there is a level of readiness to change. When readiness exists, resistance to change is reduced. Engaged employees remain enthusiastic about their organisation and choose to remain with the organisation. Change agents need to consider work engagement as an integral part of the change process, that is, before, during and after change has taken place. Work engagement and readiness to change are important elements for successful organisational change.

Research design, approach and method: A cross-sectional survey design was utilised to collect the data. A convenience sample of employees and top management from the accounting firm $(n=340)$ were included. Cronbach's alpha coefficients, Pearson's product-moment correlations, analysis of variance (ANOVA), Scheffé tests, confirmatory factor analysis and structural equation modelling were used to analyse the data.

Main findings: Results indicated a practical and statistically significant relationship between readiness to change and work engagement. High levels of work engagement will generate high levels of readiness to change. Further to this, readiness to change is influenced by employees' work engagement and an organisation's change processes.

Practical or managerial implications: An employee's work engagement and an organisation's processes of change influence an employee's readiness to change. Therefore, organisations need to sustain work engagement and improve change processes.

Contribution: The contribution of this study is that it has provided new insights into the relationships between readiness to change and work engagement in a South African context.

\section{Introduction}

\section{Purpose}

In times when change is the rule rather than the exception, the ability of organisations to be flexible has become paramount (Bouckenooghe, De Vos \& Van den Broeck, 2009). Readiness to change is essential for a change to be implemented successfully (Bouckenooghe et al., 2009). When readiness exists, the organisation is primed to embrace change and resistance could be reduced. When the converse is true, the change may be rejected. Work engagement is viewed as a workplace approach designed to ensure that employees are committed to the organisation's goals and values, motivated to contribute to organisational success and simultaneously to enhance their own sense of well-being (McLeod \& Clark, 2009). Mangundjaya (2012) believes that high work engagement encourages readiness to change. With this in mind, the purpose of this study is to determine the relationship between readiness to change and work engagement.

\section{Literature review}

Readiness to change is a critical element for the successful implementation of organisational change (Weiner, 2009), and work engagement is an important driver for organisational success (Lockwood, 2007). It is important that organisations sustain work engagement during 
organisational changes. Both readiness to change and work engagement are important aspects of a successful organisation. An introduction to the literature review will be discussed in the following section and should provide a better understanding regarding the concepts under scrutiny.

\section{Conceptual literature}

\section{Readiness to change}

Readiness to change takes its roots in early research on organisational change (Walinga, 2008). The greatest challenge lies with the common assumption in organisational change literature that employees need to 'be made ready' for organisational change (Armenakis \& Harris, 2002). Walinga (2008) explains that facilitating employee readiness to change entails exploring how leaders can 'get ready' to 'get employees ready' for change. Readiness to change emerged as one of the core attitudes affecting success and failure of change interventions (Zayim, 2010). According to Weiner (2009), it involves employees' beliefs in their potential and efficacy for the change efforts.

Readiness to change is conceived as a multifaceted concept that comprises an emotional dimension, a cognitive dimension and an intentional dimension of change (Bouckenooghe et al., 2009). Intentional readiness to change refers to the extent to which employees are willing to put their energy into the change process (Oreg, 2003). Cognitive readiness to change refers to the beliefs and thoughts that people hold about change (Oreg, 2003). According to Bouckenooghe and De Vos (2007), the cognitive component refers to what people think about change. Emotional readiness to change refers to the affective reactions towards change (Oreg, 2003). Resistance is associated with fear of the unknown. Therefore, emotional readiness is fuelled by cognitive readiness. It is believed that intentional, cognitive and emotional reactions towards change transpire at different stages in the change process and do not necessarily coincide (Bouckenooghe et al., 2009). Although this three-dimensional framework is useful in handling different aspects of changerelated attitudes of individuals, they are also dependent on each other in the way that feelings regarding change are generally associated with the thoughts and behavioural intentions about the change (Oreg, 2003). As a result, in this study, this three-dimensional framework was adopted and investigated to better comprehend readiness to change.

\section{Work engagement}

Work engagement is defined as 'a positive, fulfilling, workrelated state of mind that is characterised by vigour, dedication and absorption' (Schaufeli, Salanova, GonzalezRomá \& Bakker, 2002, p. 74). Vigour is portrayed by high levels of energy, mental resilience, willingness to invest effort, as well as persistence (Schaufeli et al., 2002). Vigour helps individuals to be more sensitive to opportunities at work and fosters a more proactive work style (Brummelhuis \& Bakker, 2012). Dedication is characterised by 'a sense of significance, enthusiasm, inspiration, pride, and challenge'
(Schaufeli et al., 2002, p. 74). Dedication is specified by enthusiasm, inspiration and pride (Bakker, 2011; Kassing, Piemonte, Goman \& Mitchell, 2012). Absorption is depicted as being engrossed in one's work, to the extent that time passes quickly and it is difficult to detach oneself from work (Schaufeli et al., 2002). Absorption entails full concentration and being highly and happily engrossed in one's work (Bakker, 2011; Kassing et al., 2012). Work engagement is a key business driver for organisational success where high levels of engagement promote retention of talent, foster customer loyalty and improve organisational performance and stakeholder value (Lockwood, 2007). Engaged employees typically remain enthusiastic about their organisation and choose to remain with the organisation (Lockwood, 2007). Further to this, employee engagement continues to be an important predictor of organisational performance even in a challenging economy (Gallup, 2013). Work engagement is influenced by many factors ranging from workplace culture, organisational communication and managerial styles to trust, respect, leadership and company reputation (Lockwood, 2007). Organisational changes that result from mergers, acquisitions, downsizing and restructuring lead to increased pressure on employees to work longer hours, take on greater responsibility and become more resistant towards continuous change and ambiguity (Burnes, 2005). The problem is exaggerated when change agents, usually management, do not include employees in the adaptation process and fail to manage the change process adequately. This mismanagement impacts negatively on organisational effectiveness and employee well-being, resulting in the employee becoming disengaged in their work and the organisation (Marks, 2007).

According to Bhola (2010), sustaining engagement throughout organisational change can make a significant difference in retaining employees and increasing performance. Change agents must consider work engagement as an integral part of the change process, that is, before, during and after change has taken place (Bhola, 2010) to ensure that the change process is successful. Further to this, the state of the global workplace report presented by Gallup indicated that employees who are engaged in their work are less likely to be thrown off course by organisational changes (Gallup, 2013). Increasing the number of engaged employees and managers driving organisational change initiatives will boost their likelihood of success (Gallup, 2013).

\section{Trust in leadership}

Because change involves deviation and a certain amount of risk-taking, employees would most likely avoid change behaviours unless they operated in a situation in which they felt secure (Tierney, 1999). Therefore, the presence of a high level of trust amongst employees represents another necessary condition for change attempts and acceptance. In organisations where trust in top management exists, and where change projects have been implemented successfully in the past, organisational members are more likely to develop positive attitudes towards new changes (Bouckenooghe et al., 2009). 
Gallup's assessment of many South African workplaces found that trust and transparent communication for organisational leaders are essential for talent management, which includes effective management of change initiatives amongst other talent management practices; therefore, organisational leaders should not overlook their impact (Gallup, 2013).

Trust in the organisation, colleagues and the leader is an antecedent of work engagement, indicating how important it is to foster an open, dependable relationship in the workplace (Bargagliotti, 2011). Further to this, when leaders display transformational leadership behaviours, it leads to higher levels of work engagement (Salanova, Lorente, Chambel \& Martinez, 2011). The relationship between trust and work engagement is mutually reinforcing and leads to an upward spiral effect (Hassan \& Ahamed, 2011). Further to this, results from a study conducted by Zayim (2010) indicated that perceived trust in colleagues, leadership and clients is correlated with perceived organisational trust and contributed significantly in readiness to change.

\section{Process of change}

The process dimensions of organisational change should involve change models, proposed for effective change implementation, and elements that contribute to the positive outcomes of the change efforts (Bouckenooghe et al., 2009). Process factors of change, specifically within this study, have a temporary nature and refer to the actual approach of implementing the change (Bouckenooghe et al., 2009). Open communication, knowledge sharing and participation are some factors that could facilitate successful change practices (Marks, 2007). Failure to do so can result in employees becoming disengaged at work (Marks, 2007). Readiness to change is also affected by the track record of an organisation in dealing effectively with change, which highlights the importance of such agents managing the change process effectively (Bouckenooghe et al., 2009).

\section{Relationships between the constructs in the study}

The motivation for this study was based on the notion that organisations need to determine the employee readiness for change before embarking on change processes, as this could possibly lead to the success or failure of planned change. A further motivation was to explore the relationship between readiness to change, work engagement, process of change and trust in leadership during a change process within an accounting firm.

A study conducted by Mangundjaya (2012) in four financial companies that consist of three private-owned banks and one government-owned financial company $(N=502)$ indicated that both organisational commitment and work engagement have a positive correlation with individual readiness to change. Mangundjaya (2012) believes that the higher the work engagement, the higher the readiness to change will be. Hung, Wong, Anderson and Hereford (2013) conducted a study amongst 706 physicians and staff in 19 primary health care departments to measure readiness to change and to determine the role of work engagement, ownership and participation in managing change. This study identified that non-physicians who reported high levels of work engagement and ownership also appeared to be ready for change (Hung et al., 2013). Further studies highlight that there is a relationship between readiness and processes of change (Jimmieson, Peach \& White, 2008; McKay, Kuntz \& Näswall, 2013; Ranta, 2011).

In a study conducted by Zayim (2010), in the education sector involving 603 teachers working at primary and secondary level public schools, identified that readiness to change and perceived organisational trust were significantly correlated with each other in a way that intentional-, emotionaland cognitive readiness were all associated and contributed significantly to perceived organisational trust. The results showed that perceived trust in colleagues, leadership and clients is correlated with perceived organisational trust and contributed significantly to readiness to change (Zayim, 2010). Myungweon (2011) also suggested certain aspects of leadership are shown to influence readiness to change. These include employees' trust in executive management, effective leadership practices and the quality of employee-manager relationships.

According to Bargagliotti (2011), trust in leadership is an antecedent of work engagement. When leaders display transformational leadership behaviours, it leads to higher levels of work engagement (Salanova et al., 2011). In a study conducted by Mahembe and Engelbrecht (2014), within the South African school system $(N=288)$, it was suggested that there is a positive relationship between trust in the leader and work engagement. Bargagliotti (2011) concluded that trust in the leader is an antecedent of work engagement. Organisational climate, such as trust in leadership, is important for establishing a positive attitude towards change. There is a limitation of available data from South Africa; therefore, this study will provide new insights into the relationships between the constructs measured in this study from a South African context. The next section will discuss the proposed model and hypotheses for this study.

\section{Proposed model}

A model for this study was constructed based on the questionnaires utilised, as well as the literature review. This model is illustrated in Figure 1.

As identified by Bouckenooghe et al. (2009), climate of change and process of change were uncovered as antecedents of readiness to change. Figure 1 illustrates that the arrows are flowing from process of change to the sub-constructs which implies that process of change will be measured by (1) participation, (2) support by supervisors, (3) attitude of top management and (4) quality of change communication. Climate of change is measured by trust in leadership, cohesion and politicking. However, this study will only focus on the trust in leadership component for which the reasons will be discussed in the research method section. Figure 1 shows that the arrows are flowing from process of change 


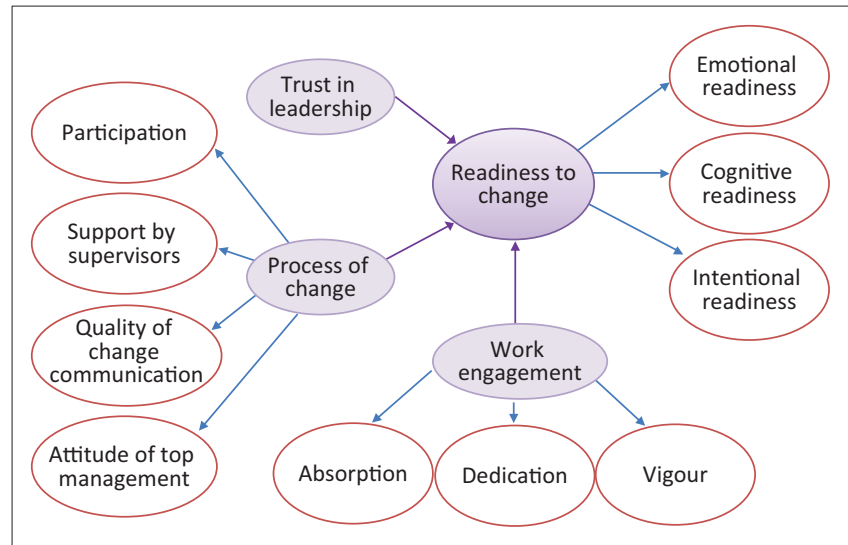

FIGURE 1: Proposed model of the relationships between work engagement, readiness to change, process of change and trust in leadership.

TABLE 1: Demographic variables of the sample.

\begin{tabular}{|c|c|c|}
\hline Demographic variables & Frequency & Percentage \\
\hline \multicolumn{3}{|l|}{ Gender } \\
\hline Male & 144 & 42 \\
\hline Female & 196 & 58 \\
\hline \multicolumn{3}{|l|}{ Language } \\
\hline English & 189 & 56 \\
\hline Afrikaans & 116 & 34 \\
\hline Xhosa & 15 & 4 \\
\hline Other African & 20 & 6 \\
\hline \multicolumn{3}{|l|}{ Job category } \\
\hline Top management & 51 & 15 \\
\hline Middle management & 120 & 35 \\
\hline Trainee accountant & 88 & 26 \\
\hline Administration & 76 & 22 \\
\hline Other & 5 & 1 \\
\hline \multicolumn{3}{|l|}{ Race } \\
\hline White & 204 & 60 \\
\hline African & 42 & 12 \\
\hline Mixed race & 57 & 17 \\
\hline Indian & 37 & 11 \\
\hline \multicolumn{3}{|l|}{ Office } \\
\hline Kimberley & 7 & 2 \\
\hline Pretoria & 42 & 12 \\
\hline Kathu & 3 & 1 \\
\hline Paarl & 6 & 2 \\
\hline Plettenberg Bay & 3 & 1 \\
\hline George & 17 & 5 \\
\hline East London & 18 & 5 \\
\hline Bloemfontein & 14 & 4 \\
\hline Port Elizabeth & 60 & 18 \\
\hline Johannesburg & 53 & 16 \\
\hline Durban & 21 & 6 \\
\hline Cape Town & 95 & 28 \\
\hline \multicolumn{3}{|l|}{ Age } \\
\hline $20-29$ & 165 & 49 \\
\hline $30-39$ & 92 & 27 \\
\hline $40-49$ & 43 & 13 \\
\hline $50-59$ & 39 & 11 \\
\hline
\end{tabular}

$n=340$.

and trust in leadership towards readiness to change. The researcher anticipates that the outcome of this study will possibly reveal a relationship between process of change and readiness to change, as well as a relationship between trust in leadership and readiness to change.
As work engagement is an important part in the change process, it could possibly have an influence on readiness to change, and for this reason, it was included in the proposed model. This is indicated in Figure 1 and is illustrated by the arrows flowing from work engagement towards the readiness to change construct. Work engagement is measured in the model by vigour, dedication and absorption. Therefore, the arrows are flowing from work engagement to the three subconstructs as can be seen in Figure 1.

The level of readiness to change is measured through the respondents' emotional-, cognitive- and intentional readiness to change. Therefore, the arrows are flowing from readiness to change towards the sub-constructs. The relationships anticipated within the proposed model will be tested and discussed in the 'Results' section.

From the literature and the proposed model, the following hypotheses were set:

- H1-1: There is a significant relationship between readiness to change and work engagement.

- H1-2: There is a significant relationship between readiness to change and process of change.

- H1-3: There is a significant relationship between readiness to change and trust in leadership.

- H1-4: There is a significant relationship between work engagement and process of change.

- H1-5: There is a significant relationship between work engagement and trust in leadership.

- H1-6: There is a relationship between process of change and trust in leadership.

\section{Method}

A descriptive research design utilising a quantitative research method was used to pursue the aim of this study. The accounting firm under scrutiny endured an integration process with an international accounting firm in 2008 introducing numerous changes which to date continues to take place. The aim for the accounting firm was to become fully integrated in a national and international capacity which implied that all the offices across South Africa would implement similar business policies, procedures and strategies and would be viewed as one practice. The mid-tier accounting firm under scrutiny has 12 offices across South Africa.

\section{Participants}

The population consisted of employees and top management within the accounting firm and was estimated at approximately 990. All employees within the accounting firm were sent an electronic survey to complete and a total of 340 responses were received, indicating a response rate of $34 \%$. The demographics of the sample are presented in Table 1.

\section{Measuring instrument}

A combined questionnaire, incorporating two measuring instruments, was utilised to gather the data for the purpose 
of this study. These instruments are the Organisational Change Questionnaire - Climate of Change, Process and Readiness (OCQ-C, P, R) as well as the Utrecht's Work Engagement Scale (UWES).

The OCQ-C, P, R, developed by Bouckenooghe et al. (2009), is a psychometrically sound diagnostic instrument that incorporates three separate questionnaires aimed at measuring the following: (1) the climate of change or internal change context $(\mathrm{C}),(2)$ the process of change $(\mathrm{P})$ and (3) readiness to change $(\mathrm{R})$. This instrument was designed to measure the circumstances under which change embarks (i.e. climate of change or internal context), the way a specific change is implemented (i.e. process) and the level of readiness at the individual level.

The instrument encompasses the following 10 dimensions: (1) quality of change communication, (2) participation, (3) attitude of top management, (4) support by supervisors, (5) trust in leadership, (6) cohesion, (7) politicking, (8) emotional readiness to change, (9) cognitive readiness to change and (10) intentional readiness to change (Bouckenooghe et al., 2009).

As mentioned before, the researcher only included the subconstruct of trust in leadership from the climate of change dimension in this study's questionnaire. Trust in leadership will be used as one of the main constructs instead of a subconstruct that measures climate of change. Politicking and cohesion were not deemed as essential components to measure by the researcher within this study. This notion was supported by the accounting firm under scrutiny. These sub-constructs could be included in future research.

Quality of change communication, participation, attitude of top management towards organisational change and support by supervisors all pertain to the process of how change is dealt with. Readiness to change was measured by emotional, cognitive and intentional readiness. Bouckenooghe et al. (2009) found that there is adequate content validity and reliability. Further to this, Bouckenooghe et al. (2009) suggested that different sections of the questionnaire could be used independently, as the scales showed adequate reliability and validity. Permission to utilise this instrument for research purposes was obtained from the developers or publishers of the scale. Respondents were asked to indicate their level of agreement with the items by using a 5-point Likert-type scale ranging from 1 (strongly disagree) to 5 (strongly agree).

Table 2 illustrates the reliability coefficients for process of change, climate of change and readiness to change. The reliability of these constructs was determined by utilising Cronbach's alpha reliability measure (Bouckenooghe et al., 2009).

From Table 2, it is evident that all sub-constructs for this questionnaire demonstrate adequate reliability which suggests that there is internal consistency (Bouckenooghe et al., 2009).
TABLE 2: Cronbach's alpha coefficients for Organisational Change Questionnaire Climate of change, process and readiness.

\begin{tabular}{ll}
\hline Construct & Alpha \\
\hline Process of change & \\
Quality of change communication & 0.88 \\
Support by supervisors & 0.82 \\
Participation & 0.79 \\
Attitude of top management & 0.73 \\
Climate of change & \\
Trust in leadership & 0.79 \\
Cohesion & 0.74 \\
Politicking & 0.68 \\
Readiness to change & \\
Emotional readiness & 0.70 \\
Intentional readiness & 0.89 \\
Cognitive readiness & 0.69 \\
\hline
\end{tabular}

Source: Bouckenooghe, D., De Vos, G., \& Van den Broeck, H. (2009). Organizational Change Questionnaire - Climate of change, processes, and readiness: Development of a new instrument. The Journal of Psychology, 143(6), 559-599. https://doi.org/10.1080/ 00223980903218216

This study utilised the UWES to measure the work engagement of respondents. The UWES includes the three constituting aspects of work engagement: vigour, dedication and absorption. According to Schaufeli, Bakker and Salanova (2006), the UWES can be used as an impartial instrument to measure work engagement because its equivalence is acceptable for different racial groups. Furthermore, confirmatory factor analyses have supported the three-dimensional structure of the UWES, and it identifies that the dimensions are very closely related (Schaufeli et al., 2006). Psychometric evaluations also illustrated satisfactory validity and reliability of the UWES (Schaufeli \& Bakker, 2003). The internal consistency of the UWES is respectable and displays Cronbach's alphas ranging from 0.80 to 0.90 in a number of studies (Schaufeli \& Bakker, 2004; Schaufeli, Taris \& Van Rhenen, 2003; Schaufeli et al., 2002). In most cases, the 3 -factor structure has been validated for the South African context (Rothmann \& Jordaan, 2006).

\section{Data collection}

It was also important to ensure that the respondents understood the items stated within the questionnaire. The pilot study was successful and all concerns were ironed out before the questionnaire was administered.

\section{Data analysis}

MS Excel applications and Statistica version 12 were applied to analyse the descriptive statistics and inferential statistics. Descriptive statistics comprised frequency distributions and measures of central tendency. Inferential statistics comprised the Pearson's product-moment correlation and multiple regression analysis. Descriptive statistics were utilised to describe the distribution of scores for readiness to change, work engagement, trust in leadership and process of change. Cronbach's alpha coefficients were calculated for each of the constructs and sub-constructs. AMOS version 23 was utilised to conduct the confirmatory factor analysis (CFA) and structure equation modelling (SEM). Table 3 summarises the reliability coefficients of overall work engagement, process of change, trust in leadership and readiness to change 
constructs. The results imply that all constructs and subconstructs utilised in the questionnaire demonstrate adequate reliability, suggesting that there is internal consistency.

For the purpose of this study, the measurement model was investigated through applying CFA. The results from CFA suggested that there was a good model fit with the data.

\section{Ethical considerations}

Before data collection could commence, the researcher had to obtain the necessary permission from the Board of Partners and also ethics approval from Nelson Mandela Metropolitan University's ethics committee. Before the researcher could administer the questionnaire, it was essential to conduct a pilot study to ensure that the link to the questionnaire was accessible from the organisation's website.

\section{Results}

To gain a better understanding of the results, the researcher presented the outcomes from the questionnaire to illustrate levels of work engagement, process of change, trust in leadership and readiness to change.

TABLE 3: Cronbach's alpha coefficients for the factors.

\begin{tabular}{lll}
\hline Construct & Sub-construct & Alpha \\
\hline Readiness to change & Emotional readiness & 0.72 \\
& Cognitive readiness & 0.74 \\
& Intentional readiness & 0.92 \\
& Total & 0.74 \\
Process of change & Quality of change & 0.94 \\
& communication & \\
& Participation & 0.90 \\
& Attitude of top & 0.91 \\
Work engagement & Support by supervisors & 0.83 \\
& Total & $\mathbf{0 . 8 6}$ \\
& Absorption & 0.78 \\
& Dedication & 0.87 \\
Trust in leadership & Vigour & 0.84 \\
\hline
\end{tabular}

$n=340$.
From Table 4, it is apparent that there are high levels of absorption, dedication and vigour within the sample. Further to this, the sample displays high levels of work engagement. Quality of change communication and participation presented medium scores. Attitude of top management and support by supervisors presented high scores. The sample has a medium score with regard to process of change. The trust in leadership construct revealed a medium score. The sample displayed high levels of emotional-, cognitive- and intentional readiness to change. Further to this, the sample possesses high levels of readiness to change.

\section{Relationship between the constructs}

Table 5 reflects the correlations between scores on readiness to change and work engagement constructs and their respective sub-constructs based on the results of Pearson's product-moment correlation calculation.

From Table 5, it is apparent that there is practically and statistically significant relationship between overall readiness to change and work engagement $(r=0.452)$. Regarding relationships between the sub-constructs of readiness to change and the sub-constructs of work engagement, Table 5 indicates that there is a practically and statistically significant relationship between emotional readiness and vigour $(r=0.370)$, intentional readiness and absorption $(r=0.28)$, intentional readiness and dedication $(r=0.407)$ as well as intentional readiness and vigour $(r=0.461)$. Table 5 also indicates that cognitive readiness has a statistical relationship with dedication $(r=0.263)$ and vigour $(r=0.260)$. Absorption's correlation with emotional readiness $(r=0.178)$ and cognitive readiness $(r=0.069)$ is relatively small.

From Table 6 , there is a correlation of 0.482 between readiness to change and process of change, indicating a practically and statistically significance between the constructs. Readiness to change displays practical and statistical significance with all the sub-constructs for process of change. Process of change also displays practical and statistical significance with the sub-constructs for readiness to change.

TABLE 4: Descriptive statistics for work engagement, process of change, trust in leadership and readiness to change.

\begin{tabular}{|c|c|c|c|c|c|c|c|}
\hline Construct & Mean & Medium & Min. & Max. & Std. Dev. & Skewness & Kurtosis \\
\hline Absorption & 3.65 & 3.67 & 1.17 & 5.00 & 0.62 & -0.303 & 0.110 \\
\hline Dedication & 3.74 & 3.80 & 1.00 & 5.00 & 0.74 & -0.459 & 0.253 \\
\hline Vigour & 3.46 & 3.50 & 1.00 & 5.00 & 0.66 & -0.334 & 0.114 \\
\hline Work engagement & 3.62 & 3.64 & 1.06 & 5.00 & 0.57 & -0.494 & 0.771 \\
\hline $\begin{array}{l}\text { Quality of change } \\
\text { communication }\end{array}$ & 2.85 & 3.00 & 1.00 & 5.00 & 0.94 & -0.016 & -0.498 \\
\hline Participation & 2.87 & 3.00 & 1.09 & 4.82 & 0.73 & -0.080 & -0.048 \\
\hline $\begin{array}{l}\text { Attitude of top management } \\
\text { towards change }\end{array}$ & 3.41 & 3.33 & 1.00 & 5.00 & 0.94 & -0.259 & -0.204 \\
\hline Support by supervisors & 3.42 & 3.43 & 1.00 & 5.00 & 0.78 & -0.191 & 0.131 \\
\hline Process of change & 3.14 & 3.15 & 1.09 & 4.95 & 0.72 & -0.055 & -0.157 \\
\hline Trust in leadership & 3.21 & 3.33 & 1.00 & 5.00 & 0.83 & -0.129 & -0.006 \\
\hline Emotional readiness & 3.48 & 3.40 & 1.80 & 5.00 & 0.67 & 0.219 & -0.027 \\
\hline Cognitive readiness & 3.40 & 3.40 & 1.40 & 5.00 & 0.65 & 0.116 & 0.348 \\
\hline Intentional readiness & 3.72 & 3.67 & 1.00 & 5.00 & 0.75 & -0.126 & 0.184 \\
\hline
\end{tabular}


TABLE 5: Correlations between the constructs of readiness to change and work engagement.

\begin{tabular}{lcccc}
\hline Constructs & Absorption & Dedication & Vigour & $\begin{array}{c}\text { Work } \\
\text { engagement }\end{array}$ \\
\hline $\begin{array}{l}\text { Emotional } \\
\text { readiness }\end{array}$ & 0.178 & 0.281 & 0.370 & 0.329 \\
$\begin{array}{l}\text { Cognitive } \\
\text { readiness }\end{array}$ & 0.069 & 0.263 & 0.260 & 0.240 \\
$\begin{array}{l}\text { Intentional } \\
\text { readiness }\end{array}$ & 0.428 & 0.407 & 0.461 & 0.509 \\
$\begin{array}{l}\text { Readiness to } \\
\text { change }\end{array}$ & 0.289 & 0.397 & 0.455 & 0.452 \\
\hline
\end{tabular}

TABLE 6: Correlations between the constructs of readiness to change and process of change.

\begin{tabular}{lcccc}
\hline Constructs & $\begin{array}{c}\text { Emotional } \\
\text { readiness }\end{array}$ & $\begin{array}{c}\text { Cognitive } \\
\text { readiness }\end{array}$ & $\begin{array}{c}\text { Intentional } \\
\text { readiness }\end{array}$ & $\begin{array}{c}\text { Readiness to } \\
\text { change }\end{array}$ \\
\hline $\begin{array}{l}\text { Quality of } \\
\text { change } \\
\text { communication }\end{array}$ & 0.320 & 0.415 & 0.217 & 0.385 \\
$\begin{array}{l}\text { Participation } \\
\begin{array}{l}\text { Attitude of top } \\
\text { management }\end{array}\end{array}$ & 0.299 & 0.465 & 0.267 & 0.419 \\
$\begin{array}{l}\text { Support by } \\
\text { supervisors }\end{array}$ & 0.285 & 0.455 & 0.336 & 0.470 \\
$\begin{array}{l}\text { Process of } \\
\text { change }\end{array}$ & 0.376 & 0.391 & 0.197 & 0.353 \\
\hline
\end{tabular}

TABLE 7: Correlations between the constructs of readiness to change and trust in leadership.

\begin{tabular}{lcccc}
\hline Constructs & $\begin{array}{c}\text { Emotional } \\
\text { readiness }\end{array}$ & $\begin{array}{c}\text { Cognitive } \\
\text { readiness }\end{array}$ & $\begin{array}{c}\text { Intentional } \\
\text { readiness }\end{array}$ & $\begin{array}{c}\text { Readiness to } \\
\text { change }\end{array}$ \\
\hline $\begin{array}{l}\text { Trust in } \\
\text { leadership }\end{array}$ & 0.340 & 0.492 & 0.311 & 0.465 \\
\hline
\end{tabular}

TABLE 8: Correlations between the constructs of process to change and work engagement.

\begin{tabular}{|c|c|c|c|c|}
\hline Constructs & Absorption & Dedication & Vigour & $\begin{array}{c}\text { Work } \\
\text { engagement }\end{array}$ \\
\hline $\begin{array}{l}\text { Quality of change } \\
\text { communication }\end{array}$ & 0.153 & 0.366 & 0.331 & 0.342 \\
\hline Participation & 0.122 & 0.365 & 0.347 & 0.336 \\
\hline $\begin{array}{l}\text { Attitude of top } \\
\text { management }\end{array}$ & 0.209 & 0.414 & 0.397 & 0.408 \\
\hline $\begin{array}{l}\text { Support by } \\
\text { supervisors }\end{array}$ & 0.176 & 0.304 & 0.307 & 0.314 \\
\hline Process of change & 0.196 & 0.427 & 0.408 & 0.414 \\
\hline
\end{tabular}

Results, as presented in Table 7, reveal a positive relationship between readiness to change and trust in leadership $(r=0.465)$. Trust in leadership demonstrates practical and statistical significance with the sub-constructs of readiness to change.

From Table 8 , there is a correlation of $r=0.414$ between work engagement and process of change, indicating a practical and statistical significance between the constructs. Table 8 illustrates that all the sub-constructs from process of change display practically and statistically significant correlations with work engagement. A noticeable result observed from Table 8 is that all the sub-constructs from process of change possess lower correlations with absorption; however, these correlations are still considered as statistically significant as $r \geq 0.106$ (Gravetter \& Wallnau, 2009).

Table 9 suggests that there is a positive relationship between work engagement and trust in leadership $(r=0.350)$. Trust in
TABLE 9: Correlations between the constructs of trust in leadership and work engagement.

\begin{tabular}{lcccc}
\hline Constructs & Absorption & Dedication & Vigour & $\begin{array}{c}\text { Work } \\
\text { engagement }\end{array}$ \\
\hline $\begin{array}{l}\text { Trust in } \\
\text { leadership }\end{array}$ & 0.132 & 0.384 & 0.351 & 0.350 \\
\hline
\end{tabular}

TABLE 10: Correlations between the constructs of trust in leadership and process of change.

\begin{tabular}{lc}
\hline Constructs & Trust in leadership \\
\hline Quality of change communication & 0.586 \\
Participation & 0.644 \\
Attitude of top management & 0.632 \\
Support by supervisors & 0.671 \\
Process of change & 0.743 \\
\hline
\end{tabular}

TABLE 11: Results for structural equation modelling for proposed model.

\begin{tabular}{lcc}
\hline Indices for single fit models & $\begin{array}{c}\text { Recommended } \\
\text { metrics }\end{array}$ & Results \\
\hline Chi-square & $\leq 3.00$ & 1.740 \\
Bentler-Bonnet Normed Fit Index (NFI) & $\geq 0.90$ & 0.830 \\
Bentler Comparative Fit Index (CFI) & $\geq 0.90$ & 0.920 \\
Joreskog Adjusted GFI (AGFI) & $\geq 0.95$ & 0.760 \\
$\begin{array}{l}\text { Root mean square approximation } \\
\text { (RMSEA) }\end{array}$ & $\leq 0.08$ & 0.047 \\
Akaike Information Criterion (AIC) & $<$ better & 3448.443 \\
Brown-Crudeck Criterion (BCC) & $<$ better & 3542.943 \\
\hline
\end{tabular}

$n=340$.

leadership demonstrates practical and statistical significance with dedication $(r=0.384)$, vigour $(r=0.351)$ and a lower significance, although still statistically significant, with absorption $(r=0.132)$.

As can be seen in Table 10, the correlation coefficient calculated for process of change and trust in leadership is 0.743 , which implies that there is a positive relationship between the constructs.

Trust in leadership demonstrates practical and statistical significance with quality of change communication $(r=0.586)$, participation $(r=0.644)$, attitude of top management $(r=0.632)$ and support by supervisor $(r=0.671)$.

\section{Structural equation modelling analysis}

Structural equation modelling analysis was utilised to evaluate the relationships amongst the set of variables used in the model proposed in this study. If the indices meet or exceed the metrics mentioned in Table 11, it will identify if there is an adequate data fit with the proposed model.

For comparing models, lower scores for Akaike Information Criterion (AIC) and Brown-Crudeck Criterion (BCC) are deemed more suitable (Hair, Black, Babin, Anderson \& Tatham, 2006; Schreiber et al., 2006; D. Venter, pers. comm., July 01, 2015). The root mean square approximation (RMSEA) is 0.047 indicating a good model fit. The Bentler Comparative Fit Index (CFI) was 0.92 indicating a conservative model fit. The chi-square was 1.74 which is below 3.00 as recommended in Table 4.47. The Joreskog Adjusted GFI (AGFI) was 0.76 which illustrates a mediocre model fit. The Bonnet Normed Fit Index (NFI) was 0.83 


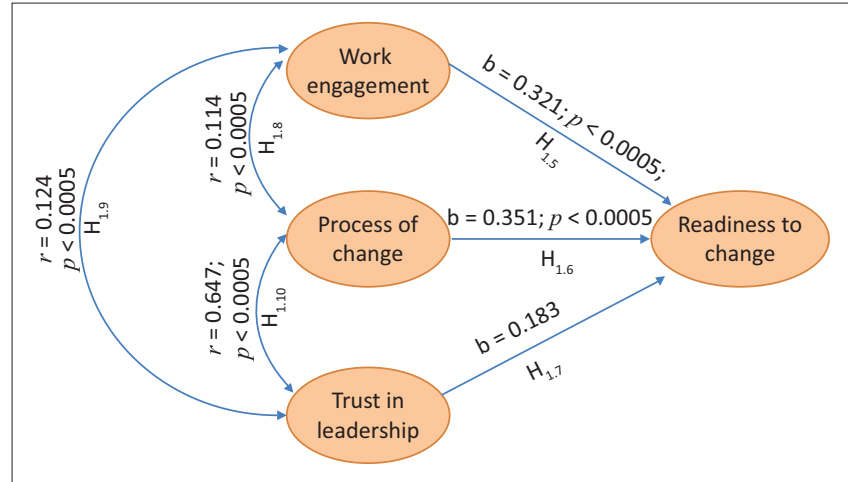

FIGURE 2: Structural equation modelling estimations $(n=340)$.

which is below the recommended 0.90 indicated in Table 10, which is not seen as a good fit.

The AMOS package utilised within this study measured the estimated relationships between constructs in the proposed model. The purpose of Figure 2 is to illustrate the relationships between the constructs.

The single-headed arrows indicate dependency type relationship, and the double-headed blue arrows indicate a covariance. Figure 2 illustrates three dependency type relationships with readiness to change and three covariances amongst process of change, trust in leadership and work engagement. The regression weights and covariances are reported as estimates, because the AMOS programme estimates these values based on the sample data. All the estimates illustrated in Figure 2 are significant $(p<0.05)$, which implies causality because of the fact that SEM was utilised. The weight of the regression of trust in leadership on readiness to change does not display significance. Although a larger sample will most likely confirm that the trust in leadership on readiness to change regression weight is actually significant, the sample size of this study is viewed acceptable for exploratory purposes.

As illustrated in Figure 2, the single-headed arrows suggest that process of change and work engagement significantly influence readiness to change $(p<0.0005)$. The dual-headed arrows suggest that process of change and work engagement is significantly correlated $(p<0.0005)$, suggesting that employees with high levels of work engagement will perceive change processes positively. This is because engaged employees will be able to deal with job demands more effectively, specifically if change processes increase job demands. It further illustrates that process of change and trust in leadership are significantly correlated $(p<0.0005)$, suggesting that if trust in leadership exist, processes of change will be perceived more favourably. A correlation is also apparent between work engagement and trust in leadership $(p<0.0005)$, suggesting that work engagement could create enhanced trust in leadership and vice versa.

The results from SEM imply that the data support the hypotheses implied by the proposed model, as mentioned earlier and indicated in Figure 2, in that process of change and work engagement influence readiness to change. However, the relationship between trust in leadership and readiness to change is not statistically significant $(p>0.05)$.

\section{Discussion Questionnaire results}

Respondents have high levels of work engagement, as can be seen in Table 4, suggesting that most of the respondents are energetic about their work, feel connected to their work and are better able to deal with job demands. Organisational changes that are a result of mergers, acquisitions, downsizing and restructuring lead to increased pressure on employees to work longer hours, take on greater responsibility and become more tolerable towards continuous change and ambiguity (Burnes, 2005) because of uncertainty and potential changes in the organisational culture. When employees are engaged, they are able to deal with job demands more effectively, particularly under circumstances of change.

The process of change results, as can be seen in Table 4, suggests that it is problematic, which may be because of the uncertainty with regard to processes around change implementation currently taking place in the accounting firm. When change agents fail to manage the process, it can lead to employees becoming disengaged in their work (Marks, 2007); however, this does not seem to be the case as engagement levels are high.

As seen in Table 4, trust in leadership appears to be low, which suggests that leadership may need to become more transparent with the activities surrounding change implementation. Although there are a percentage of respondents who perceive that trust in leadership exists, the overall score from this construct indicates that there is also room for improvement when it comes to trust in leadership for the accounting firm. It would possibly be easier for employees to go along an uncertain pathway of change when they trust their leaders who are guiding the change initiatives. Because change involves deviation and a certain amount of risk-taking, employees would most likely avoid change behaviours unless they operated in a situation in which they felt secure (Tierney, 1999). Therefore, trust in leadership during change processes is essential. In organisations where trust in top management exists, and where change projects have been implemented successfully in the past, organisational members are more likely to develop positive attitudes towards new changes (Bouckenooghe et al., 2009).

The results from this study suggest that the respondents within the mid-tier accounting firm have high levels of readiness to change, as seen in Table 4 . This implies that they support and have positive attitudes towards change that occurs within the firm or their departments. 


\section{Relationship between the constructs}

This study found that there is a relationship between readiness to change and work engagement. The latter concurs with studies conducted by Mangundjaya (2012), Prasad (2014) and Hung et al. (2013) where it was revealed that work engagement is positively related with readiness to change. This suggests that employees who support change are generally energetic about their work, feel connected to their work and are better able to deal with job demands.

There is also a significant relationship between readiness to change and process of change. This suggests that when employees are prepared for change, they will perceive change processes positively within the organisation. According to Ranta (2011), change communication was found to be an important factor in facilitating readiness to change. Ranta (2011) explains that this finding has practical significance in that communication should be considered critical in facilitating readiness to change. In a study conducted by McKay et al. (2013), it was indicated that the perceived adequacy of change-related communication was associated with participants' readiness to change.

Furthermore, there is a significant relationship between readiness to change and trust in leadership. Employees who have trust in their leaders are more ready for change than those who do not have trust. This outcome is similar to findings from a study conducted by Zayim (2010) indicating that perceived trust in colleagues, leadership and clients are all correlated with perceived organisational trust and contributed significantly in readiness to change (Zayim, 2010). Further to this, Myungweon (2011) mentioned that certain aspects of leadership, such as employees' trust in executive management, effective leadership practices and the quality of employee and manager relationships, also influence readiness to change.

The correlation between work engagement and process of change implies that respondents who are energetic about their work, feel more connected to their work and are better able to deal with job demands (high on work engagement), will generally perceive processes of change in a positive light. According Changefirst (2013), one of the major influencing factors in work engagement is the degree to which people see the organisation successfully implementing change, in other words, the processes of change. Tvedt and Buvik (2009) revealed that a healthy organisational change process can assist in shaping engagement.

In addition to this, a significant relationship between work engagement and trust in leadership is present, suggesting that when employees trust leadership, they are more engaged. Hassan and Ahamed (2011) indicated that the relationship between trust and work engagement is mutually reinforcing and leads to an upward spiral effect. According to Dirks and Ferrin (2002), an increase in trust is a direct or indirect result of positive workplace behaviours and attitudes likeorganisational commitment and employees' work engagement.
According to this study, trust in leadership is significantly related to process of change and its sub-constructs, namely quality of change communication, participation, attitude of top management and support by supervisor. When trust in leadership exists, the processes of change will be received more positively. According to Caetano and Neves (2006), trust in leadership contributes to a successful change process. Employees who have trust in leadership typically perceive change processes in a positive light as they have faith in those making the changes. The relationship between trust and change is reciprocal (Caetano \& Neves, 2006; Morgan \& Zeffane, 2003). Good processes of change implementation could also improve trust in leadership.

To support the findings from Pearson's product-moment correlations, the proposed model was tested by way of SEM from which the results illustrate that work engagement and process of change influences readiness to change. This implies that employees who are engaged in their work will be less resistant towards change; thus, improving work engagement levels of employees will lead to them supporting change initiatives. Furthermore, adequate change processes will contribute in generating support for change processes amongst employees thereby reducing resistance to change.

The SEM results further reveal that process of change and work engagement are significantly correlated, suggesting that employees with high levels of work engagement will generally perceive change processes positively. This is because engaged employees will be able to deal with job demands more effectively, specifically if change processes increase job demands.

Process of change and trust in leadership are also significantly correlated as indicated from the SEM results. As mentioned before, this suggests that when processes of change are perceived positively, employees will generally have trust in leadership. Further to this, when there is trust in leadership employees will generally perceive the change processes more positively. The SEM results further reveal that there is a significant correlation between work engagement and trust in leadership which implies that work engagement will generally enhance trust in leadership and vice versa.

\section{Limitations}

Time constraints and work pressures could have influenced the response rates, as respondents work in a time and feedriven environment. In order to overcome this, an electronic questionnaire was utilised in order for respondents to complete the questionnaire at home or in their own time.

Trust in leadership was only measured by three items as referred to in the methodology section. The researcher was aware that this could possibly influence the results for this construct. However, the results from this construct were still considered to be valuable and introduced an area for 
improvement within the accounting firm which can be potentially researched in the future.

\section{Recommendations for future research}

It would be advisable to scrutinise the concept of trust in leadership as a lack of trust in leadership can be a consequence of ineffective communication within an organisation (Lamm, Gordon \& Purser, 2010). This can be done by incorporating a larger trust scale into this study's questionnaire. Alternatively, trust in leadership could be measured as a separate construct. Another recommendation for future research would be to administer the research questionnaire utilised within this study before and after a change initiative takes place, so as to determine if the change process influenced work engagement or to assess the employees' level of readiness to change. The SEM results indicated a mediocre model fit with the data; therefore, it would be beneficial to attempt on improving the model fit. Potentially testing this model with other samples and in other industries may be beneficial.

\section{Conclusion and contribution of this study}

By understanding the relationships between readiness to change and work engagement, the mid-tier accounting firm will receive valuable information on how the integration and change processes impact employees and top management within the organisation. These findings further provide direction on how to approach future integration and change procedures. From the results of this study, it was implied that high levels of work engagement will generate high levels of readiness to change. Engaged employees are better able to cope with job demands during change processes which ultimately will impact whether change implementation is successful.

In conclusion, an employee's work engagement and an organisation's processes of change, such as quality of change communication, participation during change, attitude of top management towards change, support by supervisors and trust in leadership, influence the employees' readiness to change. Therefore, the latter elements are crucial for successful change implementation within an organisation.

\section{Acknowledgements Competing interests}

The authors declare that they have no financial or personal relationships that may have inappropriately influenced them in writing this article.

\section{Authors' contributions}

This article is based on M.M.'s degree of Doctor of Philosophy in Industrial Psychology from the Nelson Mandela Metropolitan University, South Campus. C.H. was the supervisor of the project and acted as the corresponding author.

\section{References}

Armenakis, A.A., \& Harris, S.G. (2002). Crafting a change message to create transformational readiness. Journal of Organizational Change Management, 15, 169-183. https://doi.org/10.1108/09534810210423080

Bakker, A.B. (2011). An evidence-based model of work engagement. Current Directions in Psychological Science, 20, 265-269. https://doi.org/10.1177/0963 721411414534

Bargagliotti, L.A. (2011). Work engagement in nursing: A concept analysis. Journal of Advanced Nursing, 68(6), 1414-1428. https://doi.org/10.1111/j.1365-2648. 2011.05859.x

Bhola, H. (2010). Employee engagement: The impact of change management implementation in mergers. Retrieved 14 September 2014, from http://repository. up.ac.za/handle/2263/23769?show=full

Bouckenooghe, D., \& De Vos, G. (2007). Psychological change climate as a catalyst of readiness for change: A dominance analysis. Retrieved 27 July 2014, from http:// wps-feb.ugent.be/Papers/wp_07_483.pdf

Bouckenooghe, D., De Vos, G., \& Van den Broeck, H. (2009). Organizational Change Questionnaire - Climate of change, processes, and readiness: Development of a new instrument. The Journal of Psychology, 143(6), 559-599. https://doi. org/10.1080/00223980903218216

Brummelhuis, L.L., \& Bakker, A.B. (2012). Staying engaged during the week: The effect of off-job activities on next day work engagement. Journal of Occupational Health Psychology, 17(4), 445-455. https://doi.org/10.1037/a0029213

Burnes, B. (2005). Complexity theories and organisational change. Internationa Journal of Management Reviews, 7(2), 73-90. https://doi.org/10.1111/j.14682370.2005.00107.x

Caetano, A., \& Neves, P. (2006). Social exchange processes in organizational change: The roles of trust and control. Journal of Change Management, 6(4), 351-364. https://doi.org/10.1080/14697010601054008

Changefirst. (2013, June 24). White paper: The psychology of successfully delivering organisational change. Retrieved 14 September 2014, from http://www. changefirst.com/news/white-paper-psychology-successfully-deliveringorganisational-change

Dirks, K.T., \& Ferrin, D.L. (2002). Trust in leadership: Meta analytic findings and implications for research and practice. Journal of Applied Psychology, 87 611-628. https://doi.org/10.1037/0021-9010.87.4.611

Gallup. (2013). State of the global workplace: Employee engagement insights for business leaders word wide. Retrieved 09 November 2017, from http://www. securex.be/export/sites/default/.content/download-gallery/nl/brochures/ Gallup-state-of-the-GlobalWorkplaceReport_20131.pdf

Gravetter, F.J., \& Wallnau, L.B. (2009). Statistics for the behavioral sciences (8th ed.). Belmont, CA: Wadsworth.

Goliath-Yarde, L., \& Roodt, G. (2011). Differential item functioning of the UWES-17 in South Africa. SA Journal of Industrial Psychology, 37(1), 897-908. https://doi. org/10.4102/sajip.v37i1.897

Hair, J.F., Black, W.C., Babin, B.J., Anderson, R.E., \& Tatham, R.L. (2006). Multivariate data analysis. Upper Saddle River, NJ: Pearson Education Inc.

Hassan, A., \& Ahamed, F. (2011). Authentic leadership, trust and work engagement International Journal of Social, Behavioral, Educational, Economic and Management Engineering, 5(8), 150-156.

Hung, D., Wong, E., Anderson, K., \& Hereford, J. (2013). PS2-14: Ready to change? The role of employee engagement, ownership, and participation in managing change. Clinical Medicine and Research, 11(3), 159. https://doi.org/10.3121/cmr.2013. 1176.ps2-14

Jimmieson, N.L., Peach, M., \& White, K.M. (2008). Utilising the theory of planned behavior to inform change management. The Journal of Applied Behavioural Science, 44(2), 237-262. https://doi.org/10.1177/0021886307312773

Kassing, J.W., Piemonte, N.M., Goman, C.C., \& Mitchell, C.A. (2012). Dissent expression as indicator of work engagement and intention to leave. Journal of
Business Communication, 49(3), 237-253. https://doi.org/10.1177/00219436 12446751

Lamm, E., Gordon, J.R., \& Purser, R.E. (2010). The role of value congruence in organizational change Organization Development Journal, 28(2), 49-64. Retrieved 14 September 2014, from http://www.odinstitute.org

Lockwood, N.R. (2007). Leveraging employee engagement for competitive advantage: HR's strategic role. Retrieved 12 September 2014, from https://www.shrm.org/ Research/Articles/Articles/Documents/07MarResearchQuarterly.pdf

Mahembe, B., \& Engelbrecht, A.S. (2014). The relationship between servant leadership, organisational citizenship behaviour and team effectiveness. SA Journal of Industrial Psychology, 40, 1-10. https://doi.org/10.4102/sajip. v40i1.1107

Mangundjaya, W.L.H. (2012). Are organizational commitment and employee engagement important in achieving individual readiness for change? Humanitas, 2, 185-192.

Marks, M.L. (2007). A framework for facilitating adaptation to organisational transition. Journal of Organisational Change Management, 20(5), 721-739. https://doi.org/10.1108/09534810710779126

McKay, K., Kuntz, J.R.C., \& Näswall, K. (2013). The effect of affective commitment, communication and participation on resistance to change: The role of change readiness. New Zealand Journal of Psychology, 42, 55-66.

McLeod, D., \& Clarke, N. (2009). Engaging for success: Enhancing performance through employee engagement. London: Office of Public Sector Information. 
Morgan, D.E., \& Zeffane, R. (2003). Employee involvement, organizational change and trust in management. International Journal of Human Resource Management 14(1), 55-75. https://doi.org/10.1080/09585190210158510

Myungweon, C. (2011). Employees' attitudes toward organizational change: A literature review. Human Resource Management, 50(4), 479-500. https://doi. org $/ 10.1002 / \mathrm{hrm} .20434$

Oreg, S. (2003). Resistance to change: Developing an individual differences measure Journal of Applied Psychology, 88(4), 680-693. https://doi.org/10.1037/00219010.88.4.680

Prasad, P. (2014). Factors influencing employee centric performance in industries: A lesson in human resource management. International Journal of Scientific and Research Publications, 4(3), 1-6.

Ranta, M. (2011). The impact of trust in management and quality of change communication on readiness for change. Retrieved from http://lurepository. lakeheadu.ca:8080/bitstream/handle/2453/514/RantaM2011m-1b.pdf? sequence $=1$

Rothmann, S., \& Jordaan, G.M.E. (2006). Job demands, job resources and work engagement if academic staff in Southern African higher education institutions. South African Journal of Industrial Psychology, 32, 87-96. https://doi.org/10.4102/ sajip.v32i4.247

Salanova, M., Lorente, M.L., Chambel, M.J., \& Martinez, I.M. (2011). Transformational leadership to nurses' extra-role performance: The mediating role of self-efficacy and work engagement. Journal of Advanced Nursing 67(9), 2256-2266. https:// doi.org/10.1111/j.1365-2648.2011.05652.x

Schaufeli, W.B., \& Bakker, A.B. (2003). UWES Utrecht work engagement scale: Preliminary manual (version 1). Occupational Health Psychology Unit, Utrecht University. Retrieved 17 March 2014, from http://www.beanmanaged.eu/pdf/ articles/arnoldbakker/article_arnold_bakker_7.pdf

Schaufeli, W.B., \& Bakker, A.B. (2004). Job demands, job resources and their relationship with burnout and engagement: A multi-sample study. Journal of Organizational Behaviour, 25, 293-315. https://doi.org/10.1002/job.248
Schaufeli, W.B., Bakker, A.B., \& Salanova, M. (2006). The measurement of work engagement with a short questionnaire: A cross-national study. Educational and engagement with a short questionnaire: A cross-national study. Educational and
Psychological Measurement, 66, 701-716. https://doi.org/10.1177/00131 64405282471

Schaufeli, W.B., Salanova, M., Gonzalez-Romá, V., \& Bakker, A.B. (2002). The measurement of engagement and burnout: A two sample confirmatory factor analytic approach. Journal of Happiness Studies, 3, 71-92. https://doi. org/10.1023/A:1015630930326

Schaufeli, W.B., Taris, T.W., \& Van Rhenen, W. (2003). Workaholism, burnout and engagement: Three of a kind or three different kinds of employee well-being? Applied Psychology: An International Review, 57(2), 173-203.

Schreiber, J.B., Stage, F.K., King, J., Nora, A., \& Barlow, E.A. (2006). Reporting structural equation modeling and confirmatory factor analysis results: A review. The Journal of Educational Research, 99(6), 323-338. https://doi.org/10.3200/ JOER $99.6 .323-338$

Walinga, J. (2008). Toward a theory of change readiness: The roles of appraisal, focus, and perceived control. The Journal of Applied Behavioral Science, 44, 315-347. https://doi.org/10.1177/0021886308318967

Weiner, J.B. (2009). A theory of organizational readiness for change. Implementation Science, 4, 67-75. https://doi.org/10.1186/1748-5908-4-67

Tierney, P. (1999). Work relations as a precursor to a psychological climate for change. Journal of Organizational Change Management, 12(2), 120-134. https://doi. org/10.1108/09534819910263668

Tvedt, S.D., \& Buvik, M.P. (2009). Building engagement and commitment through healthy organizational change processes: A case study looking into possibilities, limitations, and rewards. Retrieved 17 March 2014, from https://www.sintef.no/ globalassets/project/ideellfabrikk/publications/paper-puerto-rico endelig. global

Zayim, M. (2010). Investigating the relationship between primary and secondary level public school teachers' readiness for change and perceived organizational trust. Retrieved from http://etd.lib.metu.edu.tr/upload/12612345/index.pdf 